\title{
UPAYA MENGATASI PENGANGGURAN \\ DI KABUPATEN KULON PROGO
}

\author{
Oleh: Sri Sumardingsih \\ (Staf Pengajar di Fakultas I/mu Sosial Universitas Negeri Yogyakarta)
}

\begin{abstract}
This paper use 207 respondents to analyze profile and efforts to overcome unemployment problem in Kulon Progo using multi-approach of labor force. This study find that based on respondent's perception, the main sources of unemployment are lack of capital, insufficient of information, low of entrepreneurship, and low of education level. In addition, it is found also that lack of work opportunity, unavailable of work opportunity matching with their skill, age factor and lack of husband or parent support. Based on those results, the author suggests some recommendation such as: widen the work opportunity in informal sector, widen the work opportunity in agriculture sector, and empowerment program of elderly people to enhance their healthiness.
\end{abstract}

Key Words: Unemployment,

\section{A. Pendahuluan}

Masalah ketenagakerjaan merupakan masalah yang sangat rumit di dalam pembangunan ekonomi, sehingga memerlukan penanganan khusus. Keadaan yang tidak seimbang antara kemampuan negara berkembang untuk menyediakan lapangan pekerjaan dan jumlah tenaga kerja yang selalu bertambah dari waktu ke waktu menimbulkan implikasi semakin tingginya angka pengangguran. Di Daerah Istimewa Yogyakarta tingkat pengangguran terbuka mencapai 3,75\% untuk laki-laki dan 3,73 persen untuk perempuan dari jumlah 857.027 angkatan kerja laki-laki dan 727.079 tenaga kerja perempuan Berdasar hasil Rakernas 2002 angkatan kerja di Daerah Istimewa Yogyakarta mencapai 1.734.626 yang termasuk penganggur terbuka $90.436 \quad(5,21 \%)$. Sedangkan jumlah angkatan kerja perempuan 771.490. dan pengangguran terbuka ada 44.450.

Tingkat pengangguran terbuka di Kabupaten Kulon Progo menurut SUSENAS 2002 adalah sebesar 4,54 \% dari jumlah penduduk usia kerja (10 tahun ke atas). Angka tersebut lebih 
tinggi dibandingkan dengan tingkat pengangguran terbuka di Kabupaten Gunung Kidul, yakni 1,62 \%. Namun lebih rendah dari pengangguran terbuka Daerah Istimewa Yogyakarta yaitu sebesar $5,5 \%$. Menurut jenis kelamin tingkat pengangguran perempuan lebih tinggi dari tingkat pengangguran laki-laki. $5,39 \%$ untuk perempuan dan 3,64\% untuk laki-laki.

Angka pengangguran di Kabupaten Kulon Progo ini menunjukkan besarnya jumlah pengangguran. Padahal yang menjadi masalah tentang pengangguran tidak hanya besar maupun jumlahnya, namun siapa yang menganggur serta di mana mereka, serta termasuk jenis pengangguran yang seperti apa?. Data mengenai siapa yang menganggur dapat digunakan untuk membantu mengambil kebijakan dalam rangka mengatasi masalah pengangguran, sebab data ini menunjukkan dengan jelas siapa yang perlu ditangani. Akan tetapi data jumlah dan siapa yang termasuk pengangguran tidak kentara di Kabupaten Kulon Progo selama ini belum tersedia.

Konsep menganggur dan bekerja itu tidak memberikan pengertian mengenai pendapatan dan produktivitas seseorang. Padahal ini merupakan indikator ekonomi yang sangat penting. Sebagaimana dikatakan Bakir Chris Manning (1983) bahwa untuk menggambarkan masalah tenaga kerja yang sebenarnya di negara berkembang angkatan kerja tidak cukup dikelompokkan bekerja, menganggur dan setengah menganggur. Kemudian kelompok yang termasuk setengah menganggur selanjutnya dapat diklasifikasikan lagi menjadi setengah menganggur yang kentara (visible unemployment) dan setengah menganggur tak kentara (disguised unemployment).

Angka pengangguran terbuka yang cukup kecil belum tentu menunjukkan kecilnya masalah ketenagakerjaan suatu negara/daerah. Contoh, hasil Susenas 1976 diperoleh data empiris tingkat pengangguran terbuka di Indonesia yang hanya $2,3 \%$. Akan tetapi setelah dilihat lebih jauh yang tergolong bekerja penuh hanya $54,7 \%$. Setelah dilihat lebih jauh yang tergolong bekerja penuh hanya $45,3 \%$. Inilah yang melatarbelakangi perlunya studi ini, yaitu tentang profil dan upaya mengatasi pengangguran di Kabupaten Kulon Progo dengan menggunakan multi pendekatan angkatan kerja. Dengan gambaran permasalahan yang jelas dan rinci akan memberikan landasan yang realistis dalam mengambil kebijakan yang terkait dengan masalah ketenagakerjaan pada umumnya serta masalah pengangguran pada khususnya. Hasil penelitian ini akan memberikan data primer tentang jumlah pengangguran, siapa yang menganggur serta di mana terjadi pengangguran. Tanpa adanya data-data di atas pengangguran tidak akan terdeteksi dengan baik, akibatnya solusi yang 
diambil tidak akan memecahkan permasalahan pengangguran yang sebenarnya. Hal tersebut akan membawa dampak hasil pembangunan ekonomi yang diperoleh akan habis ditelan oleh penganggur yang semakin banyak jumlahnya.

Dengan orang-orang dewasa lebih baik dari pada anak-anak. Perbedaan lainnya dari pendidikan orang dewasa dan anak-anak pada dasar dari sosialisme dalam proses pendidikan. Patterson, sebagai contoh, mengemukakan bahwa pendidikan orang dewasa menemukan sebuah proses netral karena mereka tidak membutuhkan penyebaran dari tingkah laku serta perkembangan dari karakter sebagai kasus pendidikan anak.

Ringkasnya, konsep dari pendidikan orang dewasa dan sekitarnya dapat mendekati filsafat. Salah satu dugaan tentang konsep ini cenderung keduanya yaitu praktek dan teori. Orang dewasa berpendapat sebuah proses yang lebih baik dari pada sebuah keadaan, sebagai contoh, peran penting pendidikan terlihat sebagai sebuah kendaraan untuk perkembangan diri sendiri. Begitu juga konsep dari pendidikan orang dewasa sebagai sebuah proses dari menegakkan kesadaran mengakibatkan sebuah pendapat spesial dari hubungan pelajarguru. Perkara praktis ini menyenangkan dengan kurikulum, peranan guru mengajar dan metodologi pengajaran akan banyak memenuhi pada bab ini, logika mereka berkembang pada perbedaan pendapat dari tujuan pendidikan orang dewasa.

\section{B. Hasil penelitian}

\section{Keadaan Penduduk}

Jumlah penduduk di Kabupaten Kulon Progo berdasarkan data pertengahan tahun 2002 sebanyak 446.843 jiwa yang tersebar di 12 Kecamatan, dan terdiri dari 228.595 $(51,16 \%)$ adalah perempuan dan 218.248 jiwa adalah laki-laki (48.84\%) Rasio jenis kelamin pada tingkat kabupaten adalah 95, artinya setiap 100 penduduk perempuan ada 95 penduduk laki-laki. Sedangkan di tingkat Kecamatan rasio jenis kelamin tertinggi adalah di Kecamatan Samigaluh yaitu 102. Sedanngkan terendah di Kecamatan Kalibawang, yaitu 92. Jumlah rumah Tangga di Kabupaten Kulon Prgo ada 92.634.

Data tersebut merupakan data penduduk menurut usia sekolah dan belum termasuk sekolah $7 \%$, jenjang TK 3,1 \%, SD 8,9\%, SLTP 4,6\%, SLTA $5,9 \%$ PT 8,9\%. Apabila ditinjau dari jenjang pendidikan tertinggi yang ditamatkan, sebagian besar penduduk Kabupaten Kulon Progo berpendidikan SD, yaitu 29,77 \%, SLTP 29,39\% sedang penduduk yang berpendidikan tinggi hanya $4,11 \%$.

Apabila dibedakan menurut jenis kelamin belum/tidak pernah sekolah sebesar 8,00 $\%$ untuk laki-laki dan 20,17 \% untuk 
Tabel 1. Banyaknya Rumah Tangga dan Penduduk Menurut Kecamatan Di Kabupaten Kulon Progo Tahun 2002

\begin{tabular}{|l|c|c|c|c|}
\hline \multicolumn{1}{|c|}{ Kecamatan } & Rumah Tangga & \multicolumn{2}{|c|}{ P e n d u d k } & $\begin{array}{c}\text { Jumlah } \\
\text { Penduduk }\end{array}$ \\
\hline 1.Tempel & 6.653 & 15.060 & 16.122 & 31.182 \\
\hline 2. Wates & 9.642 & 23.060 & 34.378 & 47.438 \\
\hline 3. Panjatan & 7.731 & 19.023 & 20.205 & 39.228 \\
\hline 4. Galur & 6.6 .39 & 15.638 & 16.659 & 32.297 \\
\hline 5. Lendah & 8.937 & 18.554 & 19.157 & 37.711 \\
\hline 6. Sentolo & 9.952 & 9.952 & 22.358 & 23.240 \\
\hline 7. Pengasih & 9.076 & 23.747 & 24.455 & 48.202 \\
\hline 8. Kokap & 7.796 & 19.895 & 21.192 & 41.087 \\
\hline 9. Girimulyo & 5.951 & 14.321 & 14.477 & 28.798 \\
\hline 10. Nanggulan & 6.004 & 15.397 & 16.374 & 31.771 \\
\hline 11. Kalibawang & 7.744 & 15.818 & 17.228 & 33.046 \\
\hline 12. Samigaluh & 6.509 & 15.377 & 15.108 & 10.485 \\
\hline Total 2002 & $92 / 634$ & 218.248 & 228.595 & 446.843 \\
\hline Total 2001 & 90.771 & 216.545 & 227.374 & 443.819 \\
\hline
\end{tabular}

perempuan. Tidak atau belum tamat SD ada $13,83 \%$, untuk laki-laki $17,07 \%$ untuk perempuan. Sekolah Dasar 31,68 $\%$ laki-laki dan $27,24 \%$ untuk perempuan. SLTP $20,28 \%$ untuk laki-laki dan $15,24 \%$ untuk perempuan. Sedangkan untuk SMU/SMK 21,25 \% laki-laki dan 16,96\% pendidikan Diploma (D1) ke atas $4,96 \%$ untuk laki-laki dan 3, $32 \%$ untuk perempuan.

\section{Keadaan Ketenagakerjaan}

a. Komponen Tenaga Kerja

Penduduk Kulon Progo yang termasuk angkatan kerja 69,64 \% berstatus sedang mencari pekerjaan. Adapun penduduk yang termasuk bukan angkatan kerja ada 30,36 \% dengan rincian yang sekolah 14,04 $\%$, mengurus rumah tangga $9,73 \%$ dan kelompok yang lain $6.9 \%$.

b. Lapangan Pekerjaan Utama Sebagian besar penduduk Kulon Progo memiliki lapangan pekerjaan utama pada sektor pertanian, yaitu $52,09 \%$. Sedang yang bekerja di sektor industri pengolahan sebanyak $11,98 \%$, perdagangan - hotel restoran ada $13,69 \%$, keuangan persewaan dan jasa perusahaan $11,99 \%$, bangunan $6,4 \%$, angkutan dan komunikasi 2,05\%, pertambangan dan penggalian $1,9 \%$ dan jasa-jasa yang lain 0,08 \% . 
Tabel 2. Jumlah Angkatan Kerja Menurut J enis Kelamin Tahun 2003

\begin{tabular}{|c|c|c|c|}
\hline Jenis Kelamin & Frekuensi & Persen & Peersen Komulatif \\
\hline Laki - laki & 258 & 64,5 & 64,5 \\
\hline Perempuan & 142 & 35,5 & 100 \\
\hline Total & 400 & 100 & \\
\hline
\end{tabular}

c. Status Pekerjaan Utama

Status pekerjaan utama penduduk terbanyak adalah buruh yang jumlahnya mencapai 38, $24 \%$, buruh tidak tetap $20,50 \%$ sedang pekerja dibayar terdapat $19,17 \%$. Dari 7.700 orang perempuan yang bekerja $32,79 \%$ sebagai pekerja tidak dibayar.
3. Karakteristik Angkatan Kerja

a. Jenis Kelamin Angkatan Kerja

Dari 400 angkatan kerja yang diteliti sebagian besar laki-laki yaitu 258 orang $(64,5)$, sedang perempuan hanya 142 orang $(35,5 \%)$. Hal ini ditetapkan atas pertimbangan bahwa jumlah angkatan kerja laki-laki di Daerah Istimewa Yogyakarta lebih besar dari angkatan

Tabel 3. Jumlah Angkatan Kerja Menurut Kecamatan dan Jenis Kelamin Tahun 2003

\begin{tabular}{|l|r|r|r|}
\hline \multirow{2}{*}{ Kecamatan } & \multicolumn{2}{|c|}{ Jenis Kelamin } & \multicolumn{2}{c|}{ Total } \\
\cline { 2 - 3 } & \multicolumn{1}{|c|}{ Laki-laki } & \multicolumn{1}{|c|}{ Perempuan } \\
\hline Galur & 79 & 57 & 136 \\
& $19,8 \%$ & $14,35 \%$ & $34, \%$ \\
\hline Kalibawang & 68 & 49 & 117 \\
& $17 \%$ & $12,3 \%$ & $29,3 \%$ \\
\hline Sentolo & 111 & 36 & 147 \\
& $27,8 \%$ & $9 \%$ & $36,8 \%$ \\
\hline Total & 258 & 142 & 400 \\
& $64,5 \%$ & $35,5 \%$ & $100 \%$ \\
\hline
\end{tabular}

Hasil penelitian di tiga wilayah kecamatan lokasi tentang karakteristik angkatan kerja, tingkat pengangguran terbuka, tingkat setengah pengangguran kentara dan tingkat pengangguran tidak kentara serta persepsi angkatan kerja tentang sebab-sebab terjadinya pengangguran, seperti berikut. kerja perempuan. Jumlah angkatan kerja perempuan terhadap penduduk usia kerja hanya $35,68 \%$. Adapun rasio angkatan kerja perempuan terhadap penduduk usia kerja hanya $35,68 \%$. Rasio angkatan kerja perempuan terhadap penduduk usia kerja di Kabupaten Kulon Progoo datanya belum 
ada. Ini berakibat penentuan sampel angkatan kerja perempuan sementara diadakan pada data di Daerah Istimewa Yogyakarta.

Dilihat sebarannya di tiga kecamatan lokasi penelitian, jumlah angkatan kerja menurut jenis kelamin dapat dilihat pada Tabel 3.
$56,5 \%$ berumur di bawah 35 tahun, 34,8 $\%$ berumur 35 sampai dengan 54 tahun. Hanya $8,8 \%$ yang berumur 55 tahun ke atas

\section{c. Tingkat Pendidikan Angkatan Kerja}

Tingkat pendidikan angkatan kerja terbanyak adalah SLTA (4 \%), sementara

Tabel 4. Jumlah Angkatan Kerja Menurut Kelompok Umur Tahun 2003

\begin{tabular}{|c|c|c|c|}
\hline Kelompok Umur & Frekuensi & Persen & Persen Kumulatif \\
\hline $15-24$ & 100 & 25,0 & 25,0 \\
$25-34$ & 126 & 31,5 & 56,5 \\
$35-44$ & 81 & 20,3 & 76,8 \\
$45-54$ & 58 & 14,5 & 91,3 \\
$>54$ & 35 & 8,8 & 100,0 \\
\hline Total & 400 & 100 & \\
\hline
\end{tabular}

Dari tabel di atas terlihat responden terbanyak dalam penelitian ini adalah dari Kecamatan Sentolo yaitu 147 responden. Hal tersebut disebabkan karena penduduk di Kecamatan Sentolo lebih banyak dari pada di Kecamatan yang lain. Sedanngkan responden di Kecamatan Kalibawang ditetapkan paling sedikit sebab jumlah penduduknya juga paling sedikit.

\section{b. Kelompok Umur Angkatan Kerja}

Struktur umur penduduk yang bekerja merupakan data penting untuk meneliti perubahan dalam pola pekerjaan antar generasi atau mobilitas pekerjaan bagi suatu kohor (cohart) dari waktu ke waktu (Cris Manning, 1992:32). Dilihat menurut umur (lihat Tabel 4) sebagian besar angkatan kerja berumur muda, tingkat pendidikan Sekolah Dasar (SD) berada pada urutankedua (24\%) sebagaimana disajikan pada tabel 10 dan 11 dibawah ini. Demikian juga untuk tiga daerah penelitian yaitu Kecamatan Galur, Kalibawang dan Sentolo, rata-rata tingkat pendidikan tertinggi angkatan kerja adalah setingkat SLTA. Dibanding dengan dua kecamatan yang lain. Kecamatan Galur memiliki angkatan kerja dengan tingkat pendidikan SLTA paling banyak.

\section{d. Status Perkawinan Angkatan Kerja}

Dilihat dari status perkawinannya rata-rata angkatan kerja di tiga kecamatan penelitian berstatus telah kawin. Hanya sedikit yang berstatus janda atau duda. Jumlah angkatan kerja 
di kecamatan Galur yang kawin 83 orang $(20,8 \%)$, tidak kawin 49 orang $(12,3 \%)$, janda 3 orang atau (8\%) sedangkan duda hanya 1 orang atau (3\%). Untuk kecamatan Kalibawang 85 orang $(21,3 \%$ telah kawin, 29 orang atau $7,3 \%$ tidak kawin sedangkan Janda 3 orang atau $8 \%$. Total ada 117 orang atau $29,3 \%$. Kecamatan Sentolo kawin 95 orang atau $23,8 \%$, tidak kawin 49 orang atau 12,3 $\%$ janda hanya 3 orang

\section{e. Jenis Pekerjaan Utama}

Kegiatan ekonomi penduduk suatu daerah dapat tercermin dari jenis pekerjaan utama dan jenis pekerjaan tambahan. Adapun jenis pekerjaan utama menurut kecamatan di Kulon Progo tahun 2003 adalah seperti berikut.

1) Bertani; untuk kecamatan Galur 31 orang, kecamatan Kalibawang 36 orang kecamatan Sentolo 43 orang sehingga total kaum tani di Kulon Progo ada 110 orang

2) berdagang atau berjualan; kecamatan Galur terdapat 26 orang, Kalibawang 27 orang dan Sentolo 20 sehingga total ada 73 orasng.

3) Beternak; di kecamatan Galur terdapat 11 orang, kecamatan Kalibawang hanya 5 orang dan kecamatan Sentolo ada 10 orang dan jumlah ada 26 orang.

4) Buruh; di kecamatan Galur 22 orang, kecamatan Kalibawang 20 orang dan kecamatan Sentolo terdapat 54 orang sehingga total ada 96 orang
5) Lainnya; kecamatan Galur 21 orang, Kalibawang 20 orang dan Sentolo 38 orang dan total terdapat 71 orang

\section{f. Status Pekerjaan Utama (Pokok)}

Dari 376 angkatan kerja yang tergolong bekerja paling banyak berstatus sebagai usaha mandiri tanpa bantuan orang lain, yaitu sebanyak 119 orang atau $31,65 \$$, kemudian disusul buruh atau karyawan yaitu sebanyak 96 orang $(25,5 \%$ dan usaha yang dibantu orang lain ada 82 orang atau $21 \%$. Dari ke tiga kecamatan tersebut jumlah pekerja di masing-masing kecamatan adalah kecamatan Galur 93 orang, Kalibawang 99 orang, Sentolo 126 orang dan total di tiga kecamatan terdapat 376 orang.

\section{g. Tingkat Pengangguran Terbuka}

Dari ke tiga kecamatan terdapat 400 angkatan kerja yang sebagian besar berstatus pekerja, yaitu ada 376 orang (94\%). Hal ini berarti tingkat pengangguran terbuka ada 6\%. Angka ini diperoleh dari jumlah penduduk yang tidak bekerja sebanyak 24 orang dibagi jumlah angkatan kerja sebanyak 400 orang. Tingkat pengangguran terbuka ini lebih tinggi dari tingkat pengangguran terbuka di kabupaten Kulon Progo yakni $4,45 \%$.

Jika dilihat di masing-masing kecamatan, angka pengangguran terbuka $6 \%$ tersebut di atas menyebar cukup merata di tiga kecamatan lokasi penelitian. Akan tetapi secara relatif tertinggi terdapat di kecamatan Sentolo 
yaitu $2,5 \%$, dan terendah di kecamatan Kalibawang $1,5 \%$ sedangkan di kecamatan Galur 2\%.

\section{h. Tingkat Setengah Pengangguran} Setengah penganggur dapat dikelompokkan berdasarkan jumlah jam kerja dan pendapatan menjadi dua kelompok. Kelompok tersebut adalah kelompok setengah pengangguran kentara dan kelompok setengah pengangguran tak kentara. Rerata jam kerja cukup tinggi, yaitu 59,08 jam per minggu atau 8,44 jam per hari. Dari 400 angkatan kerja, sebagian besar memiliki jam kerja yang cukup tinggi, yakni 251 orang atau $62,8 \%$. Hanya 125 orang $(31,3 \%)$ yang jam kerjanya kurang dari 35 jam per minggu. Sisanya 24 orang sedang mencari pekerjaan atau pengangguran terbuka dan jam kerjanya nol.

Kondisi secara keseluruhan, baik setengah pengangguran kentara maupun setengah pengangguran tidak kentara terdapat 300 orang (75\%). Jumlah setengah pengangguran tersebut tersebar 97 orang di kecamatan Galur, 98 orang di kecamatan Kalibawang dan paling banyak di kecamatan Sentolo yakni 105 orang.

\section{i. Tingkat Setengah Pengangguran dan J enis Kelamin Angkatan Kerja}

Pengangguran terbuka didominasi oleh perempuan, yakni 20 orang dari 24 orang yang nganggur. Sebaliknya untuk kelompok bekerja penuh didominasi oleh laki-laki, yaitu 63 orang dari 76 orang. Tampaknya stereotip peran laki-laki dan perempuan masih sangat kental. Kecilnya laki-laki yang menganggur disebabkan mereka secara kultural diperankan sebagai pencari nafkah utama dalam keluarga, sekalipun mereka masih tergolong setengah penganggur. Dari 300 orang yang tergolong setengah penganggur 191 orang adalah kaum lelaki.

\section{j. Tingkat Setengah Pengangguran Kentara}

Setengah penganggur dapat dikelompokkan berdasarkan jumlah jam kerja dan pendapatan menjadi dua kelompok, yakni kelompok setengah pengangguran kentara dan kelompok setengah pengangguran tak kentara. Tingkat setengah penganggur kentara dapat dihitung dengan membandingkan antara jumlah angkatan kerja yang jam kerjanya kurang dari 3,5 jam per minggu dari jumlah keseluruhan angkatan kerja.

\section{k. Tingkat Setengah Pengangguran Tidak Kentara}

Besarnya tingkat setengah pengangguran tidak kentara dapat dihitung dengan membandingkan jumlah angkatan kerja yang jumlah jam kerjanya lebih dari 35 jam per minggu akan tetapi pendapatannya kurang dari UMR dengan angkatan kerja seluruhnya. Dari data yang diperoleh jumlah angkatan kerja yang jumlah jam kerjanya lebih dari 35 jam per minggu tetapi pendapatannya kurang dari UMR ada sebanyak 175 
Tabel 5. Sebab Terjadinya Pengangguran di Tiga Kecamatan Kulon Progo Tahun 2003

\begin{tabular}{|c|l|c|c|}
\hline No. & \multicolumn{1}{|c|}{ Sebab Terjadinya Pengangguran } & Frekuensi & $\begin{array}{c}\text { Persentase } \\
(\%)\end{array}$ \\
\hline 1. & Kekurangan modal, pendidikan rendah & 96 & 24 \\
\hline 2. & Pendidikan rendah, kurang memiliki jiwa besar & 85 & 21,25 \\
\hline 3. & $\begin{array}{l}\text { Kurangnya lapangan kerja, belum ada pekerjaan } \\
\text { yang sesuai dengan kemampuan }\end{array}$ & 85 & 21,26 \\
\hline 4. & Pendidikan rendah kurang informasi/relasi & 26 & 6,5 \\
\hline 5. & $\begin{array}{l}\text { Kurang mendapat dukungan orang tua/suami, } \\
\text { pendidikan rendah }\end{array}$ & 11 & 2,75 \\
\hline 6. & $\begin{array}{l}\text { Kurang memiliki jiwa bisnis, kurangnya lapangan } \\
\text { kerja }\end{array}$ & 23 & 5,75 \\
\hline 7. & $\begin{array}{l}\text { Belum ada pekerjaan yang sesuai dengan } \\
\text { kemampuan, kurang modal }\end{array}$ & 42 & 10,5 \\
\hline 8. & Faktor usia, kurang memiliki jiwa bisnis & 32 & 7,99 \\
\hline Jumlah & 400 & 100 \\
\hline
\end{tabular}

orang. Akhirnya tingkat setengah pengangguran tidak kentara sebesar $43,75 \%$.

\section{Persepsi Responden Terhadap Sebab-sebab Terjadinya Pengangguran}

Dari Tabel 5 tampak bahwa penyebab utama terjadinya pengangguran berdasarkan persepsi responden terdapat 207 orang, ini disebabkan oleh kurangnya modal serta rendahnya tingkat pendidikan, rendahnya jiwa bisnis, serta kurangnya informasi. Adapun sebab lain yaitu kurangnya lapangan kerja, kurang memiliki jiwa bisnis dan tidak adanya pekerjaan yang sesuai dengan kemampuannya. Jumlah termasuk golongan ini ada 150 orang. Sisanya karena faktor usia dan kurangnya jiwa bisnis ada 32 orang dan 11 orang yang lain adalah kurangnya dukungan orang tua serta rendahnya pendidikan. Sekalipun persentasenya kecil yaitu $2,75 \%$ faktor dukungan suami/keluarga cukup menarik untuk diperhatikan sebagai salah satu penyebab terjadinya pengangguran. Hal inilah pertanda bahwa masih kentalnya bias gender.

\section{Pembahasan}

Dari 400 angkatan kerja yang diteliti ditemukan tingkat pengangguran terbuka relatif kecil, yakni $5 \%$. Meskipun masih lebih tinggi dari tingkat pengangguran terbuka di Kabupaten Kulon Progo yang hanya $4,45 \%$ Sebagai penyebab keprihatinan kita bersama adalah terjadinya tingkat setengah pengangguran yang cukup tinggi yaitu sebesar $75 \%$, dengan rincian 31,25\% untuk tingkat setengah pengangguran kentara dan $43,75 \%$ untuk tingkat 
pengangguran tidak kentara. Setengah pengangguran mencerminkan pendapatan angkatan kerja dan produktivitas yang rendah.

Pada dasarnya orang berproduktivitas rendah karena empat kemungkinan. Kemungkinan pertama, disebabkan kurangnya ketrampilan. Biasanya orang kurang terampil dalam pekerjaan karena pendidikannya rendah. Pengalaman menunjukkan bahwa pendidikan yang diperoleh di sekolah kadang-kadang terlalu umum serta tidak dapat diterapkan secara langsung dalam pekerjaan. Akibatnya dapat terjadi bahwa orang yang berpendidikan agak tinggi tetap masih memiliki produktivitas yang rendah. Rendahnya produktivitas kerja dengan alasan seperti itu biasanya dapat ditingkatkan melalui latihan kerja di luar maupun di tempat kerja, namun bagaimana mengukurnya tetap masih merupakan pekerjaan yang sulit. Kemungkinan kedua yang menyebabkan rendahnya produktivitas kerja seseorang adalah kurangnya sarana penunjang. Hal ini dapat berbentuk kurangnya alat kerja, kurangnya organisasi dan manajemen pimpinan . Rendahnya produktivitas kerja karyawan dapat terjadi karena ketidakmampuan pimpinan menumbuhkan motivasi serta membina kerjasama yang baik antar pekerja., serta mengadakan pembagian kerja yang jelas antar semua karyawan. Salah penempatan juga merupakan salah satu penyebab produktivitas kerja rendah. Kemungkinan ketiga penyebab rendahnya produktivitas kerja karyawan adalah rendahnya tingkat kesehatan dan kurang gizi. Kemungkinan keempat produktivitas kerja rendah dapat juga disebabkan oleh rendahnya tingkat upah dan sistem pengupahan yang tidak mengandung sistem pemberian insentif kepada karyawan yang berprestasi baik. Upah yang rendah tidak mendorong kegairahan kerja. Upah yang rendah juga mengakibatkan tingkat kesehatan dan konsumsi yang terbatas dan oleh karenanya produktivitas kerja menjadi rendah juga.

Secara konsumtif, Kulon Progo memiliki SDM yang cukup besar sebagaimana daerah kabupaten yang lain. Secara kualitatif masih jauh dari standar. Data Biro Pusat Statistik menunjukkan bahwa jumlah penduduk Kulon Progo menurut jenjang pendidikan tertinggi yang ditamatkan sebagian besar berpendidikan SD bahkan dibawahnya. Sedangkan yang tidak pernah sekolah ada 84,02 \% laki-laki dan $4,40 \%$ untuk perempuan, SLTP dan SLTA 10,58\% untuk laki-laki dan 10,12\% untuk perempuan. Pendidikan Diploma satu (D-1) ke atas 1,13\% untuk laki-laki dan 1,04\% untuk perempuan. Kondisi ini menunjukkan rendahnya kualitas SDM yang ada. Selain dihadapkan pada rendahnya mutu tenaga kerja, permasalahan ketenagakerjaan di Kabupaten Kulon Progo juga dihadapkan pada jaminan sosial serta perlindungan 
terhadap eksploitasi tenaga kerja anakanak. Di Kabupaten Kulon Progo ditemukan 3563 anak yang terlantar dan disalahgunakan. Khusus mengenai pekerja anak, berdasarkan pendataan yang dilakukan oleh Dinas Tenaga Kerja dan Transmigrasi Propinsi Daerah Istimewa Yogyakarta ditemukan 50 perusahaan yang mempekerjakan 116 anak sebagai tenaga kerja yang tersebar di 5 Kabupaten/Kota, dan terbanyak ditemukan di Kabupaten Kulon Progo yaitu sebanyak 47 anak.

Dalam rangka mengatasi masalah pengangguran potensi sektor pertanian di Kabupaten Kulon Progo cukup besar perannya. Selain dari sisi sumber daya alamnya yang potensial , sektor pertanian juga mampu menyerap tenaga kerja lebih banyak karena cenderung bersifat padat karya. Menurut BPS Kabupaten Kulon Progo jumlah penduduk menurut lapangan pekerjaan utama menunjukkan adanya dominasi sektor pertanian, yaitu 52,09\%. Kemudian diikuti oleh perdagangan, industri pengolahan dan jasa. Sektor pertanian juga memberikan kontribusi yang cukup besar terhadap pengembangan usaha mikro atau usaha kecil, yang ternyata lebih tahan terhadap krisis ekonomi dibanding sektor sekunder dan jasa. Hal ini berarti juga akan memberikan kontribusi dalam mengatasi masalah ketenagakerjaan (pengangguran) tidak hanya untuk jangka pendek tetapi juga untuk masa yang akan datang. Bukti telah menunjukkan kepada kita bahwa jumlah pengusaha di Indonesia mencapai 33,45 juta dan terdiri dari usaha mikro sebesar 32,64 juta atau 98\%. Dari jumlah tersebut sekitar 21,49 juta $(65,2 \%)$ berada pada sektor pertanian.

Dengan memperhatikan sektor pertanian dalam arti luas maka apabila diberdayakan pada waktunya nanti akan memberikan peran dalam mengatasi pengangguran di Kabupaten Kulon Progo. Pemberdayaan sektor pertaian secara efisien, efektif dan ditunjang teknologi modern akan menjadi mega sektor yang meliputi 3 (tiga) kegiatan utama yaitu (1) sub sektor hulu yaitu kegiatan ekonomi yang menghasilkan serta menyalurkan sarana produksi usaha tani, (2) kegiatan agrobisnis atau usaha tani, (3) sub sektor hilir yaitu meliputi kegiatan pengolahan, pemasaran, dan perdagangan atau agroindustri. Di Kabupaten Kulon Progo kegiatan agrobisnis serta agroindustri memiliki prospek yang sangat potensial.

\section{Kesimpulan}

Dari analisis data terhadap 400 angkatan kerja di Kecamatan Galur, Kalibawang dan Sentolo, dapat disimpulkan sebagai berikut.

1. Karakeristik Angkatan kerja

a. Dilihat menurut jenis kelamin, terdiri atas $258(64,5 \% 0$ laki-laki dan 142 (35,5\%) perempuan

b. Menurut kelompok umur, sebagian besar berusia muda (15-44 tahun) yakni 56,5\%, 
sisanya $14,5 \%$ berusia antara 45-54 tahun dan sebagian kecil ( $8,8 \%$ berusia di atas 55 tahun.

c. Menurut tingkat pendidikan, terbanyak adalah berpendidikan SLTA yaitu sebesar 49\%, kemudian berpendidikan dasar hingga SLTP sebanyak 43,3\% dan yang berpendidikan tinggi hanya $7,8 \%$.

d. Menurut status perkawinan, sebagian besar responden berstatus kawin, yaitu $65,8 \%$, tidak kawin $31,8 \%$ dan $2,3 \%$ berstatus janda dan 0,2 \% berstatus duda

2. Tingkat Pengangguran Terbuka Dilihat menurut status angkatan kerja, terdapat $94 \%$ atau 376 orang yang berstatus pekerja, dan hanya 24 orang atau $6 \%$ berstatus sedang mencari pekerjaan. Hal ini menunjukkan bahwa tingkat pengangguran terbuka di Kabupaten Kulon Progo tahun 2002 yaitu sebesar $4,45 \%$.

3. Tingkat Setengah Pengangguran Kentara (bekerja kurang dari 35 jam per minggu, ternyata cukup tinggi yakni $31,25 \%$.

4. Tingkat Setengah Pengangguran Tidak Kentara yaitu yang bekerja lebih dari 35 jam per minggu tetapi penghasilannya kurang dari $\mathrm{Rp}$ 363.000,- (UMR), cukup tinggi yaitu sebesar $43,75 \%$.
5. Keinginan mencari pekerjaan ternyata tidak hanya datang dari mereka yang tergolong penganggur terbuka, akan tetapi juga pada mereka yang sudah bekerja.

Total yang masih ingin mencari pekerjaan sebanyak 197 orang, terdiri dari mereka yang masih berstatus pengangguran terbuka ( 24 orang), berstatus setengah pengangguran (147 orang) dan berstatus bekerja penuh 26 orang. Mereka yang masih mencari pekerjaan sebagian besar berusia muda, antara 15 - 44 tahun, berpendidikan SLTP hingga SLTA, berstatus kawin dan memiliki beban tanggungan keluarga hanya 1 atau 2 orang.

6. Sebab-sebab terjadinya pengangguran, menurut persepsi responden karena kurangnya modal dan rendahnya tingkat pendidikan atau keterampilan, rendahnya jiwa bisnis, serta kurangnya informasi. Penyebab lainnya adalah kurangnya lapangan pekerjaan, belum adanya pekerjaan yang sesuai dengan kemampuan, atau karena faktor usia serta kurangnya dukungan dari suami atau orang tua.

7. Upaya untuk mengatasi pengangguran yang terjadi diturunkan dari persepsi angkatan kerja terhadap sebab-sebab terjadinya pengangguran, seperti:

a. memberikan bantuan modal 
b. penyelenggaraan pendidikan dan pelatihan

c. mengupayakan tambahan lapangan kerja baru

d. meningkatkan ketersediaan layanan informasi kerja

e. penyelenggaraan pendidikan dan pelatihan entrepreneurship

f. mengupayakan pendidikan yang sesuai dengan tuntutan pekerjaan (link and match)

g. pemberdayaan penduduk lansia Selain upaya tersebut, secara sektoral diperlukan langkah strategis guna mengatasi masalah pengangguran di Kulon Progo, yakni dengan memberdayakan atau mengatasi perilaku ekonomi di sektor pertanian dan sektor informal.

\section{E. Rekomendasi}

1. Dari kajian data sekunder diketahui bahwa ketersediaan data ketenagakerjaan di Kulon Progo masih terbatas sekali . Oleh karena itu Biro Pusat Statistik Kabupaten Kulon Progo perlu segera melengkapi tentang ketenagakerjaan yang dipilih menurut jenis kelamin. Data-data yang perlu diadakan antara lain data tentang:

a. Penduduk yang berumur a5 tahun ke tas menurut Kecamatan dan kegiatan seminggu sekali.

b. Penduduk berusia 15 tahun ke atas yang termasuk angkatan kerja menurut golongan umur dan pendidikan tertinggi yang diutamakan.

c. Penduduk yang berumur 15 tahun ke atas yang termasuk angkatan kerja menurut Kecamatan dan golongan umur.

d. Penduduk yang berumur 15 tahun ke atas yang termasuk angkatan kerja menurut kecamatan dan pendidikan tertinggi yang ditamatkan.

e. Penduduk berumur 15 tahun ke atas yang bekerja selama seminggu yang lalu menurut golongan umur dan pendidikan tertinggi yang ditamatkan.

f. Penduduk berumur 15 tahun ke atas yang bekerja selama seminggu yang lalu menurut umur dan jam kerja seluruhnya.

g. Penduduk berumur 15 tahun ke atas yang bekerja selama seminggu yang lalu menurut golongan umur dan pekerjaan utama.

h. Penduduk berumur 15 tahun ke atas yang bekerja selama seminggu yang lalu menurut pendidikan tertinggi yang ditamatkan dan jam kerja seluruhnya.

i. Penduduk berumur 15 tahun ke atas yang bekerja selama seminggu yang lalu menurut jumlah jam serta pendidikan tertinggi yang ditamatkan. 
j. Penduduk berumur 15 tahun ke atas ang bekerja selama seminggu yang lalu kerja menurut jumlah jam kerja pada pekerjaan utama dan status pekerjaan utama.

k. Penduduk berumur 15 tahun ke atas yang termasuk pengangguran terbuka menurut kecamatan dan pendidikan tertinggi yang ditamatkan.

I. Penduduk berumur 15 tahun ke atas yang termasuk pengangguran terbuka menurut golongan umur dan kategori pengangguran terbuka.

m. Penduduk berumur 15 tahun ke atas yang termasuk pengangguran terbuka menurut pendidikan tertinggi yang ditamatkan dan kategori pengangguran terbuka.

n. Penduduk berumur 15 tahun ke atas menurut golongan umur dan klasifikasi pengangguran.

2. Memperluas Kesempatan Kerja di Sektor Pertanian

Mengingat paling banyak angkatan kerja yang bekerja di sektor pertanian yaitu 110 orang atau $29,25 \%$ dari 376 orang, berarti sektor ini sangat potensial untuk mengatasi masalah pengangguran di Kulon Progo. Sehingga pemberdayaan sektor pertanian terutama usaha agro bisnis serta agroindustri merupakan langkah strategis untuk mengatasi pengangguran. Pemberdayaan sektor pertanian dalam rangka memecahkan masalah ketenagakerjaan sekaligus perekonomian ini sangat perlu ditunjang oleh berbagai pihak yang terkait, antara lain sektor perbankan, lembaga alternatif seperti perusahaan modal ventura (PMV). Dengan keterlibatan aktif pemerintah sangat dimungkinkan diperolehnya sumber-sumber dana murah, baik berupa soft loan, grant ataupun sumber dana yang lain, yang dijadikan sebagai pinjaman atau penyertaan pada PMV tersebut.

Selain itu sangat diperlukan dukungan dalam wujud kemauan politik dari Pemda Kulon Progo (Dinas terkait: Pertanian, Kehutanan/Perkebunan, Tenaga Kerja, Bappeda, dan Dinas terkait yang lain untuk mewujudkan keberpihakan kepada sektor pertanian secara jelas, tegas, terencana baik dalam bentuk kebijakan secara makro maupun secara mikro.

Langka tersebut sesuai dengan persepsi para angkatan kerja dalam penelitian ini bahwa faktor penyebab utama terjadinya pengangguran di Kulon Progo adalah sebagai besar 207 orang atau $51,75 \%$ karena kurangnya modal dan rendahnya 
pendidikan, rendahnya jiwa bisnis serta kurangnya informasi.

3. Memperluas Kesempatan Kerja di Sektor Informal

Dilihat menurut status pekerjaan pokok, cukup besar angkatan kerja yang termasuk dalam kelompok "berusaha sendiri tanpa bantuan orang lain", yakni sebanyak 119 orang atau $31,6 \%$. Temuan ini menjadi indikator cukup banyaknya angkatan kerja di sektor informal diakui sebagai katup pengaman masalah pengangguran serta keresahan sosial. Untuk itu pemberdayaan sektor ini merupakan langkah yang strategis pula. Di Kulon Progo keberadaan sektor ini cukup banyak meliputi penjaja makanan/usaha warung, perdagangan asongan/PKL, ojek, pemulung pekerja bangunan, perempuan pekerja rumahan, pembantu rumah tangga, perbengkelan pertanian/ perikanan kecil, nelayan kecil dan sebagainya. Dalam rangka pembinaan sektor informal ini perlu adanya sikap atau kebijakan terpadu dari Pemda (Bupati) melalui Dinas-dinas terkait, misalnya Dinas Tenaga Kerja, Dinas Perindag serta dinas terkait yang lain, dengan pola:

a. Menunjuk lokasi tertentu, jika perlu jam tertentu

b. Dengan lokasi yang tetap dan ditunjuk sesuai dengan tata kota.
Dengan demikian sektor informal sekaligus dapat merupakan sasaran pendapatan daerah secara lebih tertib dan teratur.

c. Pengembangan usaha melalui perkreditan candak kulak atau bentuk kredit mini, atau melalui modal ventura.

d. Melalui wadah koperasi serba usaha yang dimulai dengan kegiatan simpan pinjam, sehingga sektor informal akan mampu mengembangkan usahanya secara lebih mandiri.

e. Mendorong sektor informal yang ada menjadi usaha formal, misal warung nasi menjadi restoran , pedagang kaki lima menjadi toko dan sebagainya.

f. Mengalihkan usaha yang kurang memiliki prospek ke bidang usaha lain yang lebih prospektif.

g. Merencanakan lokasi yang baru bagi usaha sektor informal yang menimbulkan kerugian sosial.

h. Meningkatkan kemampuan dalam usaha sektor informal yang sama dengan melengkapi peralatan yang dibutuhkan. Berbagai perubahan yang diinginkan terhadap pelaku usaha sektor informal dalam rangka mengatasi pengangguran dibutuhkan perencanaan yang baik.

4. Terkait dengan rendahnya kualitas angkatan kerja dilihat dari rendahnya 


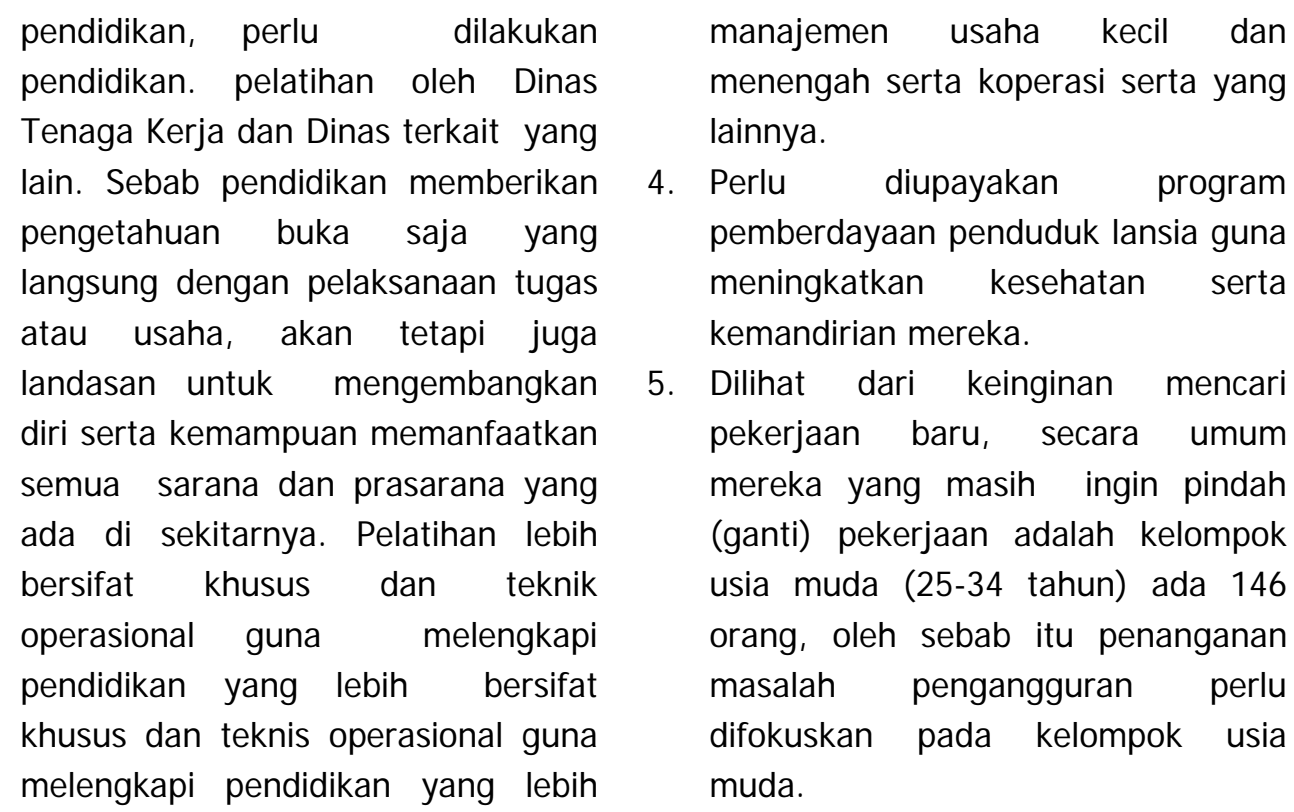

\section{Daftar Pustaka}

Badan Pusat Statistik Kabupaten Kulon Progo, SP 2000, Hasil Sensus Penduduk

Badan Pusat Statistik Provinsi Daerah Istimewa Yogyakarta, 2002, Statistik Kesejahteraan Rakyat

Biro Pusat Statistik Kabupaten Kulon Progo, 2002, Kulon Progo Dalam Angka

Glas Burner, 1977. Teori dan Kebijakan Ekonomi Makro. Program Perencanaan Nasional, FEUI- BAPPENAS Lembaga Penerbit FEUI J akarta.

Hadari Nawawi dan H.M. Martini Hadari, 1990, Administrasi Personil Untuk Meningkatkan Produktivitas Kerja, Haji Masagung, Jakarta.

Hauser, Philip M, 1974, The Measurement of Labour Utilization< Malaysia Economic Review.

Manning Cris, 1983, Kegiatan Ekonomi Angkatan Kerja, Lapangan Pekerjaan, Jenis dan Status Pekerjaan, dalam Peter F. Mc. Donald, Pedoman Analisis Sensus 19711980. Canbera, Australia.

Payaman J. Simanjutak, 1985, Pengantar Ekonomi Sumber Daya Manusia, Lembaga Penerbit Fakultas Ekonomi UI, Jakarta. 
Ravianto, 1985, Produktivitas dan Manajemen, Lembaga Sarana Informasi Usaha dan Produktivitas, J akarta.

Radmana Hands, 1977. Metode Baru dalam Pengukuran Angkatan Kerja, Lembaga Kependudukan UGM, Yogyakarta.

Salvatore, 1977, Development Economic, Mcgraw-hill Book Company, Schaumm'sOutline Series in Economic. New York.

Taddjudin Noer Effendi, 1987, Makalah Lokakarya Pendidikan Kependudukan dan Lingkungan Hidup, 6-7- Maret, Pusat Penelitian Kependudukan dan Pusat Penelitian Lingkungan Hidup UGM, Yogyakarta.

White, Benyamin. 1973, Peranan Anak Dalam Ekonomi Rumah Tangga Desa Di Jawa, Prisma, 24 Agustus.

Zainab Bakir dan Chris Manning, 1983, Partisipasi Angkatan Kerja, Kesempatan Kerja dan Pengangguran Di Indonesia. Pusat Penelitian dan Studi Kependudukan UGM, Yogyakarta.

Labour Force Situation in Indonesia, Keadaan Angkatan Keerja Di Indonesia, Agustus, 2002.

Pusat Studi Wanita Universitas Negeri Yogyakarta, 2003, Profil Kesejahteraan dan Perlindungan Anak di Propinsi Daerah Istimewa Yogyakarta. 